\title{
VERA RUDNEVA
}

\section{Innovation Potential for the Reindustrialisation of Eastern Siberia (Example of Krasnoyarsk and Irkutsk)}

\begin{abstract}
The report provides an assessment of the innovation factor in the reindustrialisation of Eastern Siberia, based on data on R\&D costs and the introduction of innovative products. The Krasnoyarsk Territory has the greatest innovative potential, followed by the Irkutsk Region. The terms of modernisation of industrial complexes in Krasnoyarsk and Irkutsk were compared on the basis of the triple helix model. This model formalises the interrelation of production with university education and the development of interaction between all parties of the innovation process. The leadership of the Krasnoyarsk Territory was confirmed by a more developed innovation infrastructure of universities that interact with local engineering and aerospace corporations. Industrial production of the Irkutsk oblast is more focused on the extraction of minerals and the production of primary processing goods due to its more eastern position and dependence on the needs of the Chinese market.
\end{abstract}

Keywords: Eastern Siberia; innovation factor; model of triple helix interaction; potential for reindustrialisation; reindustrialisation

Received: 4 December 2018

Accepted: 22 February 2019

\section{Suggested citation:}

Rudneva, V. (2019). Innovation Potential for the Reindustrialisation of Eastern Siberia (Example of Krasnoyarsk and Irkutsk). Prace Komisji Geografii Przemyslu Polskiego Towarzystwa Geograficznego [Studies of the Industrial Geography Commission of the Polish Geographical Society], 33(4), 165-175. doi: $10.24917 / 20801653.334 .10$

\section{INTRODUCTION}

Eastern Siberia (Republics of Buryatia, Tuva and Khakassia, Krasnoyarsk and Trans-Baikal Territories, Irkutsk Region) is one of the important industrial macro-regions of Russia. During the period of large-scale industrialisation (1950-1970) a powerful electric power system and transport infrastructure were constructed in the region with the formation of large territorial productive complexes. Smelting of ferrous and non-ferrous metals, wood processing and pulp and paper production were developed in 
these industrial complexes on the base of fuel and mineral resources. In the transition period (the 1990s) in Siberia, as well as in Russia as a whole, there was a decline in the activity of the development of natural resources and industrial production. Thus for the period from 1990 to 1999 the volume of industrial production in Siberia decreased by $47 \%$ (Kiselnikov, Scherbak, 2015). The aim of development of the eastern regions in the current period includes not only restoration of the industrial potential of Siberia, but also its transfer to an innovative development path. The possibility of such a transition is influenced by many factors including territorial differences in resources, the existing industrial structure, training, as well as the possibility of entering foreign markets. For forecasting the development of industry on a new technological basis an assessment of the innovation potential in the regions of Eastern Siberia is required.

At present, in planning documents of Russia, reindustrialisation is understood as the transfer of the economy to an innovative development path, where one of the main indicators should be the growth in the number of industrial enterprises engaged in technological innovations and an increase in the country's share in the global market for high-tech industries (Kontseptsiya..., 2008). At the regional level this process is also being developed in strategic planning documents, for example, state and targeted programs for the development of Siberia, the Far East and the Baikal region (Strategiya..., 2009, Strategiya..., 2010).

The understanding of processes of industrialisation and post-industrialisation that was laid down in works of W. Rostow (1959), D. Bell (1986), J.K. Gelbraith (2004), E. Toffler (2005) et al. was later continued in studies of reindustrialisation. This term implies the modernisation of all technological structures, the replacement of obsolete technologies with modern ones, the innovative renewal of production, as well as the qualitative transformation of the economic system of the region or the country. In papers of Camarinha-Matos (2013), V. Micic (2015), E. Westkamper (2014), C. Russu (2010), W. Zhao, H. Yan, H. Liu (2014) et al. the essential role of the innovation component as the main factor of the production process in the 21st century is underlined. M. Porter (2000) talks about advantages for innovation and productivity growth in clusters in comparison with isolated firms due to proximity of sources for new components, services, equipment and other elements necessary for creating innovations. P. Brezdeń (2018) in his work on the spatial differentiation of the innovation industry in Poland, points to the importance of innovation processes for economic development at a regional level, where the distribution of endogenous resources depends on the close ties of the participants. Collaboration of business, universities and the state at a given locality was formalised by H. Etzkowitz and L. Leydesdorff (2000), in a triple helix model, and this pattern was used in economic development strategies of the US (Report..., 2012), China (Yudina, 2015) and EC (The European..., 2012). Innovations are the factor that allows countries or regions to overcome the inertia of development, developed under the concept of "path dependence" of P. David (2006), B. Arthur (1989), S. Page (2006).

In Russia attention to the restructuring and modernisation of industry appeared in the 1990s, when the need to restore the industrial potential after the transformation crisis became obvious. S. Bodrunov and his co-authors (2013) stressed the importance of the scientific and technological potential for the re-industrialisation of the Russian Federation. O. Sukharev (2014) considers re-industrialisation as a new economic policy, i.e. an economy of an innovative type (overhauling modernisation, with the substitution 
of imported technologies). A number of works in Russia are devoted to problems of regional re-industrialisation - V. Kuleshov, V. Seliverstov (2015), O. Romanova, N. Bukhvalov (2014), G.A. Khmeleva, N.M. Tyukavkin, S.V. Sviridova, D.A. Chertopyatov (2017). The research of I. Danilov, S. Mikhailova, N. Morozova, T. Ladykova (2016), N. Novikova (2017) to determine the potential of re-industrialisation and its elements are of particular interest, since evaluation serves as an important means for optimising scientific, personnel, investment and other strategic initiatives. This approach included assessment of four components - production capacity, human resources, innovation, and investment potentials of the Ural region (Novikova, 2017), and this work has formed the basis for assessing the innovation potential of Eastern Siberia.

\section{METHODS}

Innovation potential was calculated on the basis of five indicators - the share of the region in the all-Russian internal costs of $\mathrm{R} \& \mathrm{D}\left(\mathrm{x}_{1}\right)$, in technological innovation costs $\left(\mathrm{x}_{2}\right)$ and in the amount of innovative products produced $\left(\mathrm{x}_{3}\right)$, as well as innovation activity of organisations $\left(\mathrm{x}_{4}\right)$ and the share of expenditures on R\&D in the gross regional product (GRP) $\left(\mathrm{x}_{5}\right)$. All calculations were made on the basis of data and index indicators of the Federal State Statistics Service for years of 2010-2016 (Regiony Rossii..., 2019).

When mixing the indicators into the index (I) of the potential, the standardisation method was used because of the high variation of the values.

$$
f_{\mathrm{i}}=\frac{\mathrm{x}_{\mathrm{i}}}{\max \left(\mathrm{x}_{\mathrm{i}}\right)}
$$

where:

$\mathrm{x}_{\mathrm{i}}$ is a value of a particular indicator of the region;

$\max \left(\mathrm{x}_{\mathrm{i}}\right)$ is a maximum value of the indicator among all regions of Eastern Siberia;

$f_{i}$ - the value of each assessment indicator.

The range of values obtained by this method varies from 0 to 1 , where the maximum value is assigned to 1.0000 .

The I itself is formed as an arithmetic average of the normalised values of all indicators of the index.

$$
\mathrm{F}_{\text {int. }}=\frac{1}{5}\left(\sum_{i=1}^{5} f_{i}\right)
$$

where:

$\mathrm{F}_{\text {int. }}$ is the synthetic index of each indicator of I evaluation.

This approach allows you to compare the degree of influence of indicators included in this I for every region of the study area.

Then, a triple helix model of H. Etzkowitz and L. Leydesdorff (2000) was applied to assess the position and compare the scientific and technical base of the two largest centres of Eastern Siberia - Krasnoyarsk and Irkutsk. A balanced triple helix model suggests the synergy of 3 institutional areas: universities (science and education), industry (business) and the state (government), on the "overlap" of which the innovation system is formed. Data from regional and city administrations, research centres of universities and educational institutions on the innovation infrastructure related to the industry of the cities were used for modelling. 


\section{RESULTS AND DISCUSSION OF THE INNOVATION POTENTIAL ASSESSMENT}

According to the results of the evaluation of the innovation potential of the Eastern Siberia regions, the absolute leader is the Krasnoyarsk Territory, which has values equal to 1.0000 for all five sub-indices (Figure 1). Irkutsk Region, the second largest industrial region of the Eastern Siberia, halved its position for the period from 2010 to 2016 (I decreased from 0.7594 to 0.3513 ) which can be explained by the increase of the share of extractive industries in the industrial complex. High growth rates of oil production did not require constant increases in scientific and innovation support.

Figure 1. The innovation potential of the Eastern Siberia regions

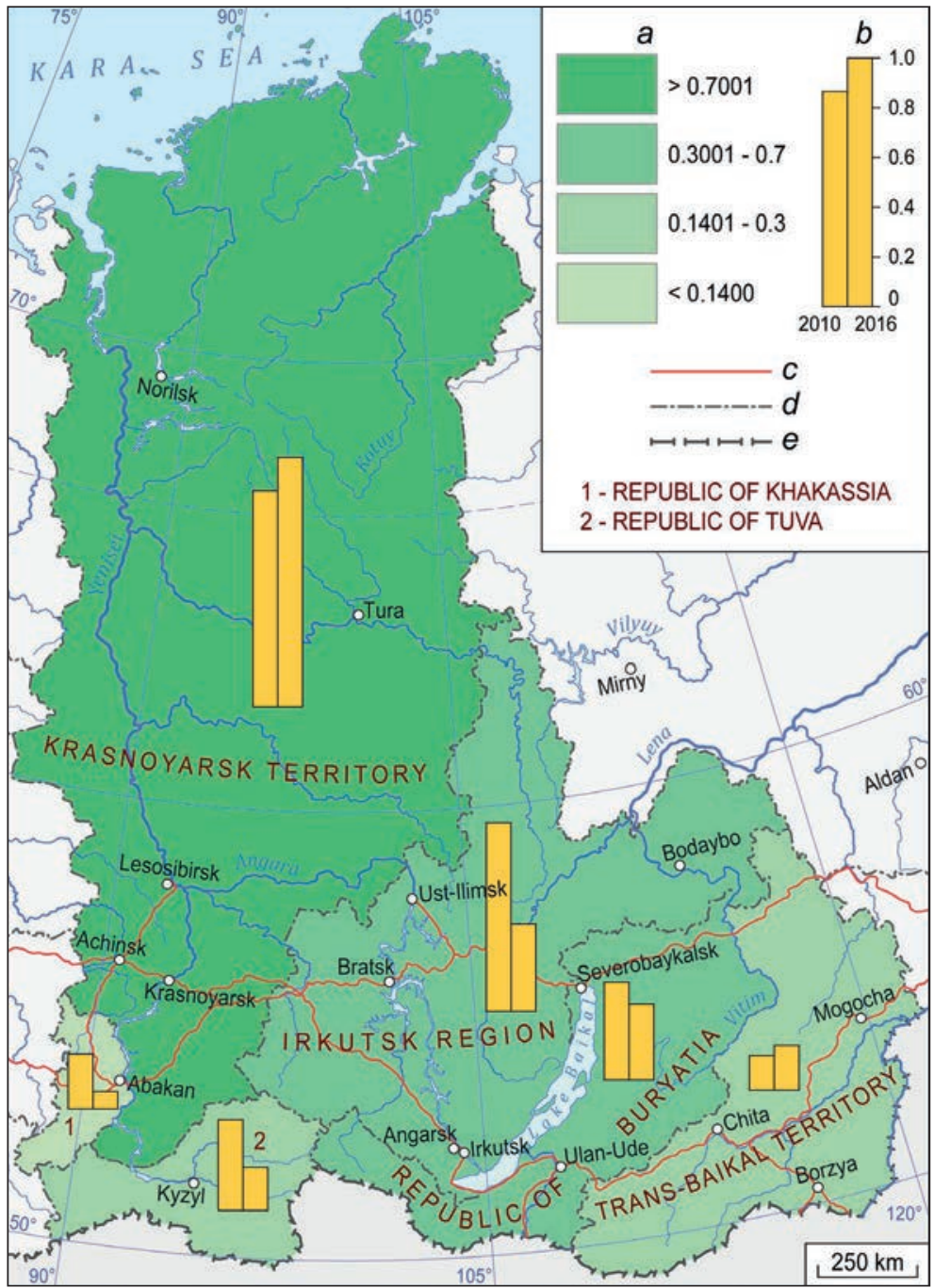

Note: a - innovation potential in 2016; b - innovation potential dynamics; c - railways, $d$ - borders of subjects of the Russian Federation, e - state borders of the Russian Federation.

Source: author's own work 
The Republic of Buryatia was third ( $\mathrm{I}=0.3053)$, remaining at the same level, since there were no significant changes in its industrial structure with a large share of high-tech engineering. Behind them are the Trans-Baikal Territory ( $\mathrm{I}=0.1778)$, the Republic of Tuva ( $\mathrm{I}=0.1740)$ and the Republic of Khakassia $(\mathrm{I}=0.0703)$. It should be noted that at the beginning of the study period, Tuva became the leader in terms of the share of R\&D expenditures in the structure of GRP and in the innovation activity of organisations due to the start of a new project of Chinese investors with modern technology for deployment of coal mining. But in six years these indicators dropped sharply, as production reached a planned level. Due to innovation activity of organisations in the engineering industry Buryatia shares leadership with the Krasnoyarsk Territory.

In general, the rest of the subjects with the exception of the Krasnoyarsk Territory have a decrease in the innovation potential and an increase in the volatility of the subjects' positions in relation to each other over the study period. The main reason is the inconsistency of the innovation policy pursued by regional authorities, which does not lead to sustainable growth.

The number of enterprises producing innovations has not increased over the past 10 years (since 2006). The share of the Eastern Siberia in the national expenditures on technological innovations was $4 \%$ in 2016, $75 \%$ of them were in the Krasnoyarsk Territory (Table 1). In 2010 this indicator was more than 6\% (of which the share of the Krasnoyarsk Territory was 57\%). In 2016, the volume of produced innovative products in the Eastern Siberia accounted for $2 \%$ of a national one, of which $72 \%$ came from the Krasnoyarsk Territory (in $2010-0.6 \%$ and $63 \%$, respectively). This dominance of the Krasnoyarsk Territory is due to the growth of investment into R\&D activities $(139 \%$ over 6 years). In the rest of the regions of Eastern Siberia the investment flow remained almost at the same level (Regiony Rossii..., 2019). Most investment projects are still focused on the development of primary industries.

Table 1. Some indicators reflect innovation activities in Eastern Siberia and Russia in 2010 and 2016 (million rubles)

\begin{tabular}{|l|r|r|r|r|}
\hline \multirow{2}{*}{} & \multicolumn{2}{|c|}{ Technological innovation costs } & \multicolumn{2}{c|}{$\begin{array}{r}\text { Volume of innovative products } \\
\text { produced }\end{array}$} \\
\cline { 2 - 5 } & 2010 & \multicolumn{1}{|c|}{2016} & 2010 & 2016 \\
\hline Russian Federation & $400,803.8$ & $1,284,590.3$ & $1,243,712.5$ & $4,364,321.7$ \\
\hline Irkutsk Region & $9,966.0$ & $9,977.8$ & $2,282.7$ & $11,812.2$ \\
\hline Krasnoyarsk Territory & $14,617.7$ & $38,440.1$ & $4,957.2$ & $63,138.7$ \\
\hline Republic of Buryatia & 461.6 & $1,769.7$ & 137.8 & $2,296.9$ \\
\hline Republic of Khakassia & 48.3 & 29.8 & 31.6 & 106.6 \\
\hline Republic of Tuva & 68.7 & 5.5 & 44.8 & 51.0 \\
\hline Trans-Baikal Territory & 457.6 & 828.6 & 446.5 & $9,752.9$ \\
\hline
\end{tabular}

Source: author's own work based on Regiony Rossii. Sotsial'no-ekonomicheskiye pokazateli (2019)

\section{CASES OF KRASNOYARSK AND IRKUTSK}

The main centres of reindustrialisation of Eastern Siberia are the regional capitals Krasnoyarsk and Irkutsk, which show different trends in the implementation of the innovation factor. 
When using the triple helix model (Etzkowitz, Leydesdorff, 2000), it is necessary to take into account institutional and other differences between Russia and the countries where this model was created. In this model the knowledge space is based on universities, which the authors prefer over applied research by firms due to the focus of universities on the formation of engineers of the future. In addition, the fundamental science in these countries is concentrated in universities. This research is also based on universities, adding to them the potential of academic science (in both cities there are research centres of the Russian Academy of Sciences). Models of cities are shown in Figure 2 and 3.

Krasnoyarsk is the largest industrial city in Eastern Siberia. During the period of deindustrialisation, a number of large manufacturing plants ceased to exist. Nevertheless, this city managed to maintain and develop a fairly strong economy. Currently, the city has a diversified industrial structure, where the leading industries are: aerospace, non-ferrous metallurgy, mechanical engineering, woodworking, chemical and pharmaceutical, food, etc. (see the "business" block in Figure 2) (Programma sotsial'no..., 2011).

A model of industry development in Irkutsk (Figure 3) is different from the previous one. Currently, the economy of the city is based on energy plants, aircraft industry, mechanical engineering, food processing and pharmaceutical enterprises. The main

Figure 2. Model of balanced reindustrialisation of Krasnoyarsk

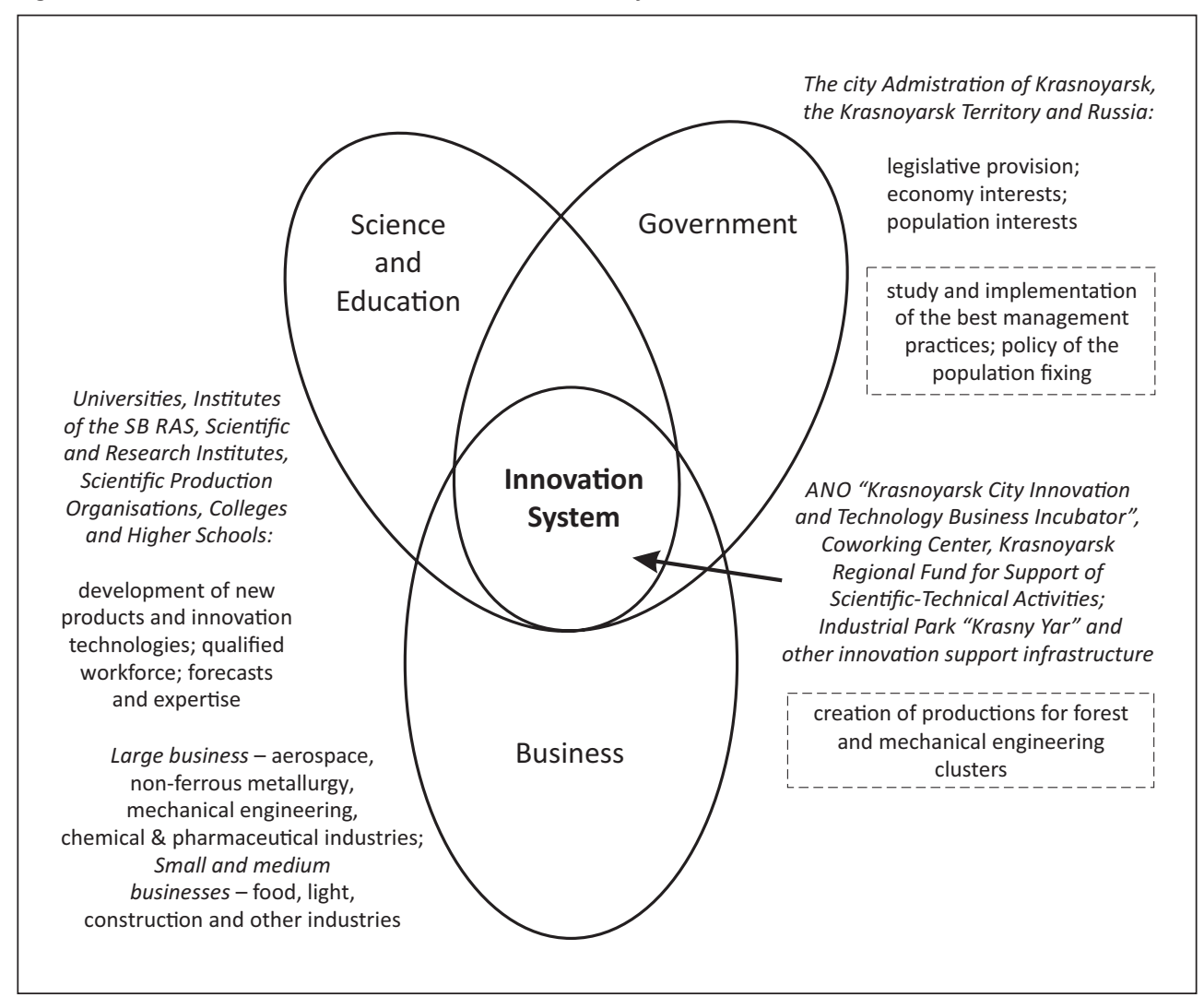

Source: author's own work based on Etzkowitz, Leydesdorff (2000) 
plants and enterprises were constructed in the period of large-scale post-war industrialisation (Korytny, 2017). Diversification of the machine-building industry in Irkutsk is significantly lower than in Krasnoyarsk, and only the aircraft plant actually forms the industrial support for innovation.

A comparison of the university and academic sectors of the two cities shows the advantage of Krasnoyarsk in relation to the innovation infrastructure. The Siberian Federal University has an innovation consulting centre which includes 22 small innovative enterprises with about half of them operating in the technical sphere. Yet the greatest contribution to the creation of innovations is made by the Reshetnev Siberian State University of Science and Technology formed by association of aerospace and technology universities. This university includes 6 scientific and training centres, supplemented by a shared resource centre, a student centre and an interregional innovative centre. At the same time, the university cooperates with enterprises in the region, including PJSC "Information Satellite Systems", the Special Construction Office "Science", the Krasnoyarsk Machine-building Plant, etc.

There are also two universities in Irkutsk, but the innovation infrastructure is represented only in the Irkutsk National Research Technical University. It is formed by a technology park with 27 training and research laboratories and 30 small enterprises,

Figure 3. Model of industrialisation of Irkutsk

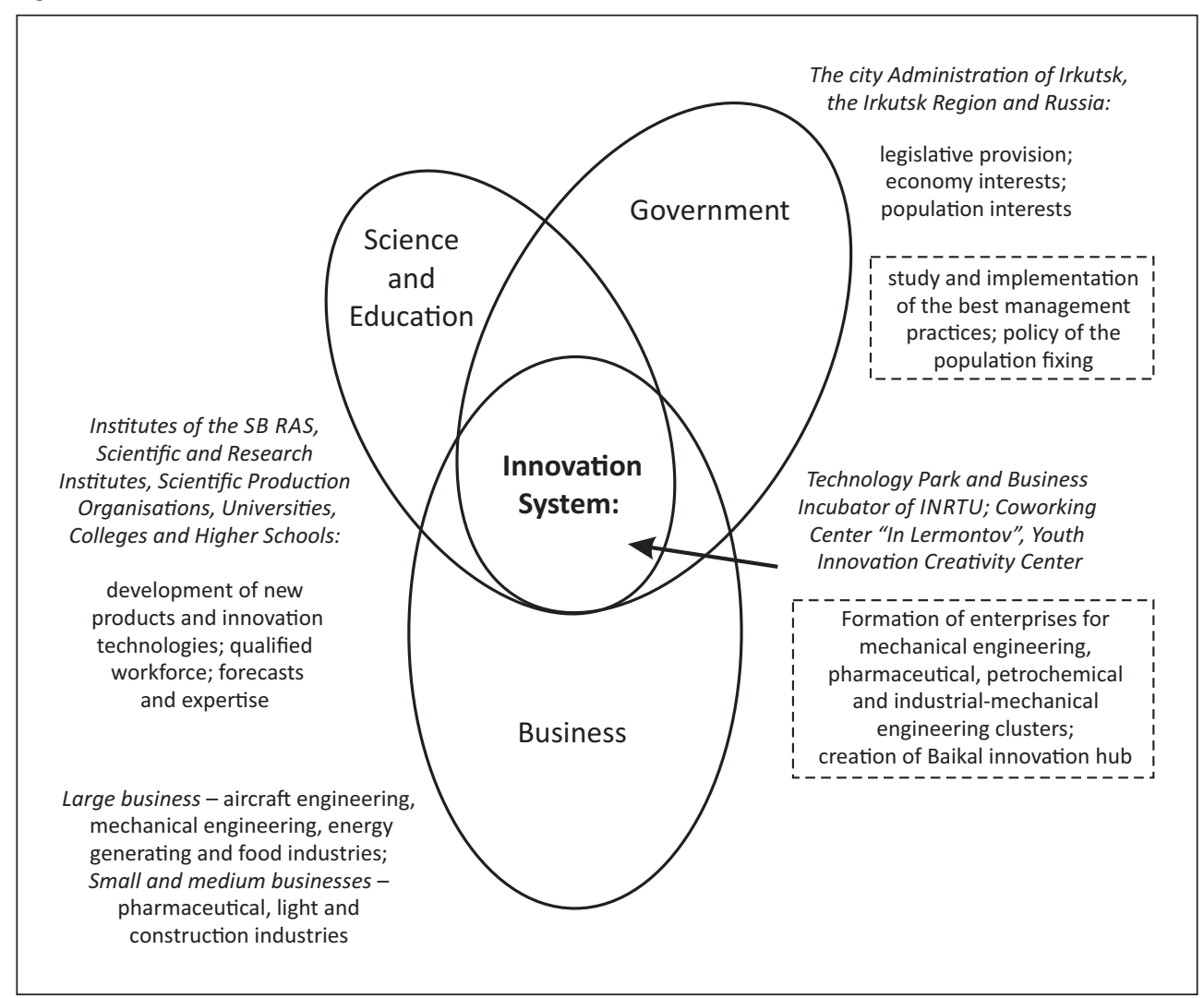

Source: author's own work based on Etzkowitz, Leydesdorff (2000) 
a business incubator with 6 residents, a student business accelerator, a startup school for innovators and a co-working centre. However, only two large manufacturing contractors have been announced - the aircraft plant and the UC Russian Aluminum. Closer interaction, among other things, is hampered by the fact that these enterprises belong to corporations that are external to the region, i.e. decisions on technological innovations and reconstruction are made under the influence of external factors, including corporate strategy.

But the institutes of the Academy of Sciences are more developed in Irkutsk. The Irkutsk Scientific Center of the SB RAS includes 17 institutes, while the Krasnoyarsk Scientific Center - 10. At the same time, in both centres only a few organisations can deal with the item of reindustrialisation - the energy and chemical institutes in Irkutsk and the chemical and physical institutes in Krasnoyarsk, as much of the research at both centres is related to Earth sciences. The innovation and educational potential of both cities is more closely connected to local technical universities than to the Academy of Sciences. The number of academic institutes in the centres increased after the integration of state academies; as a result they included institutes with medical and agricultural subjects of study.

The communication space in the triple helix model is largely determined by the state, since the sphere of initiative and independent entrepreneurship of individuals without the help of the state is small compared with developed countries. The environment of interaction between knowledge and business is governed by federal laws, but regional and municipal authorities are active actors in this process. Due to centralisation, their powers are small, financial resources are also inadequate to support innovative and entrepreneurial activity in a particular region. All the regional strategies of socio-economic development are focused on technological renewal of the production base, but this depends on the investment and innovation policies of the largest economic actors of Eastern Siberia. The main difference between these industrial centres is due to this point. In the Krasnoyarsk Territory some key corporations are registered here and so they have lower level of decision-making, which facilitates the work of the regional governments in coordinating the interests of education, science and industry. In addition, the structure of production and the high proportion of machine engineering and military enterprises contribute to the development of contacts and interconnections between all sides of the production process. In contrast, the machine-building cluster in the investment strategy of the Irkutsk Region is actually being formed around one enterprise - the aircraft plant. The policy of production clustering proclaimed by both regions is easier to implement under conditions of industrial diversification.

The results of the efforts of the federal and regional authorities to stimulate technological renewal of production can be explained using the concept of "path dependence". Eastern Siberia since the days of the planned economy was engaged in the extraction and primary processing of natural resources with the absence of competition, so the corporations has no incentive to drastically upgrade production and obtain new modern products. To implement re-industrialisation on a new technological basis, or its updates it is necessary to introduce additional conditions of functioning, i.e. to perform a "path creation" (Garud et al., 2010). The example of Krasnoyarsk shows the role of the military-industrial complex in creating a new path as a stimulator of new developments. The industrial regions located to the East and South are losing their innovation potential due to their orientation towards the Chinese semi-products market 
(Figure 1), and obviously this will continue and intensify in the future as the cost of getting out of this rut is too high for the business of the region.

State regulation in this area should have a sectoral character and potential industries for creating new products are oil and gas processing and timber industry. The institutions that form the current pattern of production starting with resource distribution must be revised and improved with the help of regional and local authorities. One of the most important measures is the restriction of export of unprocessed products. However, the case with the program for the renewal of the forest industry "Biorefinery of the Future" in Sweden shows that much of the barriers to renewal are typical not for region but for the industry as a whole (Coenen et al., 2015).

\section{CONCLUSIONS}

Eastern Siberia, which have lost part of its production capacity during the transformation period, faces the task of restoring industrial production on a new technological basis. The main innovative potential of reindustrialisation is concentrated in the Krasnoyarsk Territory and the Irkutsk Region, the rest of the regions of Eastern Siberia form a peripheral zone. This potential is reduced compared to other industrial regions of the country due to the focus of new ventures and projects on the development of mineral resources. Comparison of two regional centres with the help of the triple helix model shows the advantage of Krasnoyarsk over Irkutsk, both due to the developed innovation infrastructure at the universities of Krasnoyarsk, and due to a larger share of the processing industry in the industrial structure, including mechanical engineering. It facilitates the action of regional authorities to stimulate cooperation between business and science and creation of innovative technologies. In addition, due to its geographical position, Irkutsk is more dependent on the Chinese market which requires raw materials and products of primary processing. In general, a decrease in potential for technological improvement of the Siberian industry in the course of reindustrialisation can be observed from West to East of the region with increasing importance of raw materials extraction for the industry.

\section{References}

Arthur, B. (1989). Competing Technologies, Increasing Returns, and Lock-In by Historicalt Events. The Economic Journal, 99(394), 116-131.

Bell, D. Sotsial'nyye ramki informatsionnogo obshchestva (1986). In: P.S. Gurevich (ed.). Novaya tekhnokraticheskaya volna na Zapade. Moscow: Progress, 330-342.

Bodrunov, S.D., Grinberg, R.S., Sorokin, D.E. (2013). Reindustrializatsiya ekonomiki Rossii: imperativy, potentsial, riski. Ekonomicheskoye vozrozhdeniye Rossii [The Economic Revival of Russia], 1(35), 19-49.

Brezdeń, P. (2018). Research topics and changes in the spatial structure of innovativeness of Polish industry in 2005-2015. Prace Komisji Geografii Przemyslu Polskiego Towarzystwa Geograficznego [Studies of the Industrial Geography Commission of the Polish Geographical Society], 32(4), 205-226. doi: 10.24917/20801653.324.13

Camarinha-Matos, L.M. (2013). Collaborative Systems in Support of Reindustrialization. PRO-VE, IFIP AICT 408, 3-10. Retrieved from https://www.academia.edu/6489710/Collaborative_ Systems_in_Support_of_Reindustrialization (date of access: November 20, 2018).

Coenen, L., Moodysson, J., Martin, H. (2015). Path Renewal in Old Industrial Regions: Possibilities and Limitations for Regional Innovation Policy. Regional Studies, 49(5), 850-865. 
Danilov, I.P., Mikhailova, S.Yu., Morozova, N.V., Ladikova, T.I. (2016). Prakticheskiye aspekty otsenki potentsiala reindustrializatsii federal'nykh okrugov RF [Practical Aspects of Assessing Reindustrialization Potential of the Federal Districts of the Russian Federation]. Vestnik ekonomiki, prava i sotsiologii [The Review of Economy, the Law and Sociology], 4, 23-26.

David, P. (1985). Clio and the economics of QWERTY. Economic History, 75(2), 332-337.

Etzkowitz, H., Leydesdorff, L. (2000). The dynamics of innovation: from National Systems and "Mode 2" to a Triple Helix of university-industry-government relations. Research Policy, $29,109-123$.

Galbraith, J.K. (2004). Novoye industrial'noye obshchestvo [The New Industrial State, 1967]. Moscow: AST.

Garud, R., Kumaraswamy, A., Karnoe, P. (2010). Path Dependence or Path Creation? Journal of Management Studies, 47(4), 760-774. doi: 10.1111/j.1467-6486.2009.00914.x

Kiselnikov, A.A., Scherbak, I.V. (2015). Strukturnyye izmeneniya v ekonomike sibirskogo regiona: dinamika i otsenka tendentsiy [Structural changes in the economy of the Siberian region: the dynamics and trend assessment]. Voprosy statistiki, 4, 75-77.

Khmeleva, G.A., Tyukavkin, N.M., Sviridova, S.V., Chertopyatov, D.A. (2017). Klasternoye razvitiye regiona na osnove innovatsiy $\mathrm{v}$ usloviyakh sanktsiy (na primere neftekhimicheskogo kompleksa Samarskoy oblasti) [Cluster development of the region on the basis of innovation under the sanctions (case study of the petrochemical complex in the Samara Oblast)]. Ekonomicheskiye i sotsial'nyye peremeny: fakty, tendentsii, prognoz. [Economic and Social Changes: Facts, Trends, Forecast], 10(5), 83-98. doi: 10.15838/esc/2017.5.53.6

Kontseptsiya sotsial'no-ekonomicheskogo razvitiya RF do 2020 goda (2008, 21 November). Retrieved from http://74330s020.edusite.ru/DswMedia/koncepciyadolgosrochnogosocialnoyekonomicheskogorazvitiyarossiyskoyfederaciinaperioddo2020goda.pdf

Korytny, L. (ed.) (2017). Geograficheskaya entsiklopediya Irkutskoy oblasti. Obshchiy obzor [Geographical Encyclopedia of Irkutsk Oblast. A General Overview]. Irkutsk: V.B. Sochava Institute of Geography Publisher.

Kuleshov, V.V., Seliverstov, V.E. (2015). Programma reindustrializatsii ekonomiki Novosibirskoy oblasti: ideologiya razrabotki i osnovnyye napravleniya realizatsii. [Program for reindustrialization of the economy of Novosibirsk oblast: Ideology and main directions for its implementation]. Region: ekonomika i sotsiologiya [Region: Economics and Sociology], 3(87), 88-122.

Micic, V. (2015) (2018, 20 November). Reindustrialization and structural change in function of the economic development of The Republic of Serbia. Economic Horizons, 17(1), 15-32. Retrieved from http://www.horizonti.ekfak.kg.ac.rs/sites/default/files/Casopis/2015_1/ EN/Vladimir_Micic_EN.pdf

Novikova, N.V. (2017). Metodologiya vyyavleniya potentsiala novoy industrial'noy modernizatsii v prostranstve makroregiona. In Ya.P. Silin (ed.), Regional'naya ekonomika: vyzovy, prioritety, strategicheskiye oriyentiry. Ekaterinburg: Publishing House of the Ural State Economic University, 152-171.

Page, S. (2006). Path Dependence. Quarterly Journal of Political Science, 1, 87-115.

Porter, M.E. (2000). Location, Competition and Economic Development: Local Clusters in the Global Economy. Economic Development Quarterly, 14(1), 15-31.

Programma sotsial'no-ekonomicheskogo razvitiya goroda Krasnoyarsk do 2020 g. (2018, 8 October). Utv. resheniyem Krasnoyarskogo gorodskogo Soveta Deputatov Krasnoyarskogo kraya ot 13.10.2011 g. № V-267. Retrieved from: http://docs.cntd.ru/document/432908739

Regiony Rossii. Sotsial'no-ekonomicheskiye pokazateli, (2019, 15 January). Retrieved from: http://www.gks.ru/wps/wcm/connect/rosstat_main/rosstat/ru/statistics/publications/ catalog/doc_1138623506156

Report McKinsey Global Institute (2012) (2018. 15 November). Manufacturing the future: The next era of global growth and innovation. Retrieved from: https://www.mckinsey.com/business-functions/operations/our-insights/the-future-of-manufacturing

Romanova, O.A., Buhvalov, N.Yu. (2014). Reindustrializatsiya kak opredelyayushchaya tendentsiya ekonomicheskogo razvitiya promyshlennykh territoriy [Reindustrialization as a determinative tendency of economic development in industrial territories]. Fundamental'nyye issledovaniya [Fundamental research], 6, 151-155. 
Rostow, W.W. (1959). The Stages of Economic Growth. The Economic History Review, New Series, 12(1), 1-16.

Russu, C. (2010) (2018, 20 November). Getting out of the Crisis by Reindustrialization and a New Strategy of Romania's Economic Development. Petroleum-Gas University of Ploiesti BULLETIN, 62(4), 53-65. Retrieved from http://www.upg-bulletin-se.ro/archive/2010-4/ 6.\%20Russu.pdf

Strategiya sotsial'no-ekonomicheskogo razvitiya Dal'nego Vostoka i Baykal'skogo regiona na period do 2025 goda (2009) (2018, 21 November). Retrieved from http://docs.cntd.ru/document/902195483.

Strategiya sotsial'no-ekonomicheskogo razvitiya Sibiri do 2020 goda (2010) (2018, 21 November). Retrieved from http://docs.cntd.ru/document/902229380.

Sukharev, O.S. (2014). Reindustrializatsiya ekonomiki i tekhnologicheskoye razvitiye [Reindustrialization of economy and its technological development]. Mir novoy ekonomiki [The world of new economy], 2, 21-28.

The European Union explained: Europe 2020: Europe's growth strategy (2012) (2018, 15 November). Retrieved from http://www.antagonistikotita.gr/uploads/europe_2020explained.pdf.

Toffler, E., Toffler, H. (2005). Voyna i antivoyna [War and anti-war, 1995]. Moscow: AST.

Westkämper, E. (2014). Towards the Re-Industrialization of Europe. A Concept for Manufacturing for 2030. Berlin: Heidelberg.: Springer-Verlag.

Yudina, T.N. (2015). Deindustrializatsiya i novaya industrializatsiya (reindustrializatsiya): Rossiya i Kitay. Teoreticheskaya ekonomika [The theoretical economy], 1, 76-78.

Zhao, W.B., Yan, H.Y., Liu, Y. (2014) (2018, 20 November). Impacts of US Reindustrialization on Chinese Manufacturing. Open Journal of Social Sciences, 2, 139-143. Retrieved from http://file.scirp.org/pdf/JSS_2014082709465233.pdf.

Vera Rudneva, Eng., Irkutsk Scientific Center SB RAS, Department of Regional Economic and Social Problems. She is working as an engineer in The Department of Regional Economic and Social Problems of the Irkutsk Scientific Center of SB RAS and is a postgraduate in V.B. Sochava Institute of Geography of SB RAS. Her research areas are industrial geography, economic development and city-industry relation. She has published several papers in journals and conference papers on industrial geography, economic development, revitalisation of old industrial town and territories, reindustrialisation of Baikal Region, Eastern Siberia and Siberia as a whole.

ORCID: 0000-0003-4505-4662

\section{Address:}

Irkutsk Scientific Center of SB RAS

Department of Regional Economic and Social Problems

134, Lermontov st., 664033, Irkutsk, Russia

e-mail: varud8892@yandex.ru 